\title{
Synthesis of 2D Hexagonal Hematite Nanosheets and the Crystal Growth Mechanism
}

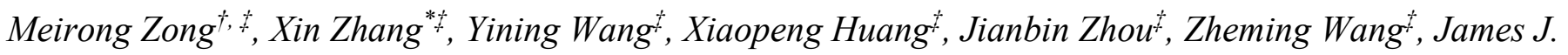

De Yoreo ${ }^{\dot{t}, \xi}$, Xiancai Lu ${ }^{* \dagger}$ and Kevin M. Rosso ${ }^{* \neq}$

${ }^{\dagger}$ School of Earth Sciences and Engineering, Nanjing University, Nanjing, Jiangsu 210023, China

$\ddagger$ Physical \& Computational Science Directorate, Pacific Northwest National Laboratory, Richland, Washington 99354, United State

$\S^{\S}$ Department of Materials Science and Engineering, University of Washington, Seattle, Washington 98195 , USA

\section{Corresponding Authors}

E-mail: Xin.Zhang@pnnl.gov (X.Z); xcljun@nju.edu.cn (L.X.); Kevin.Rosso@pnnl.gov (K.M.R.). 


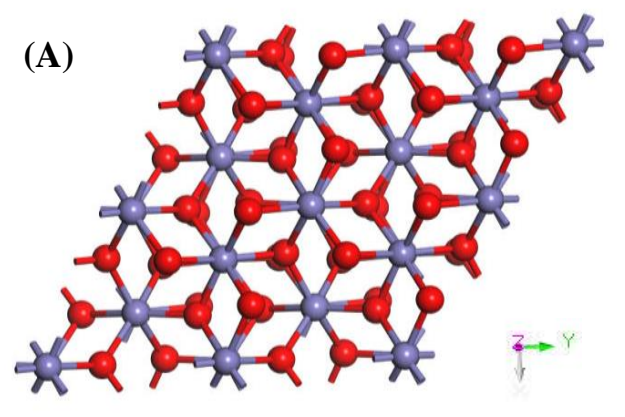

(B)

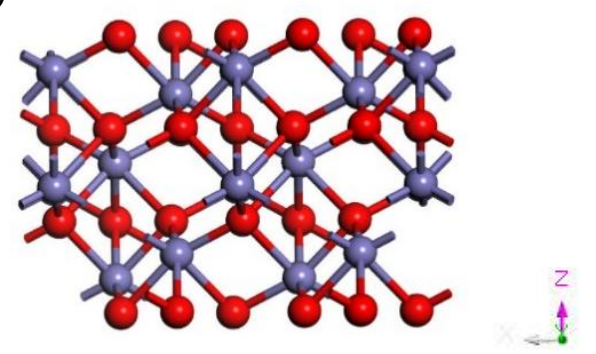

Figure S1. Crystal structure of hematite $\alpha-\mathrm{Fe}_{2} \mathrm{O}_{3}$, (A) top view along $\{001\}$; (B) side view along $\{001\}$. 


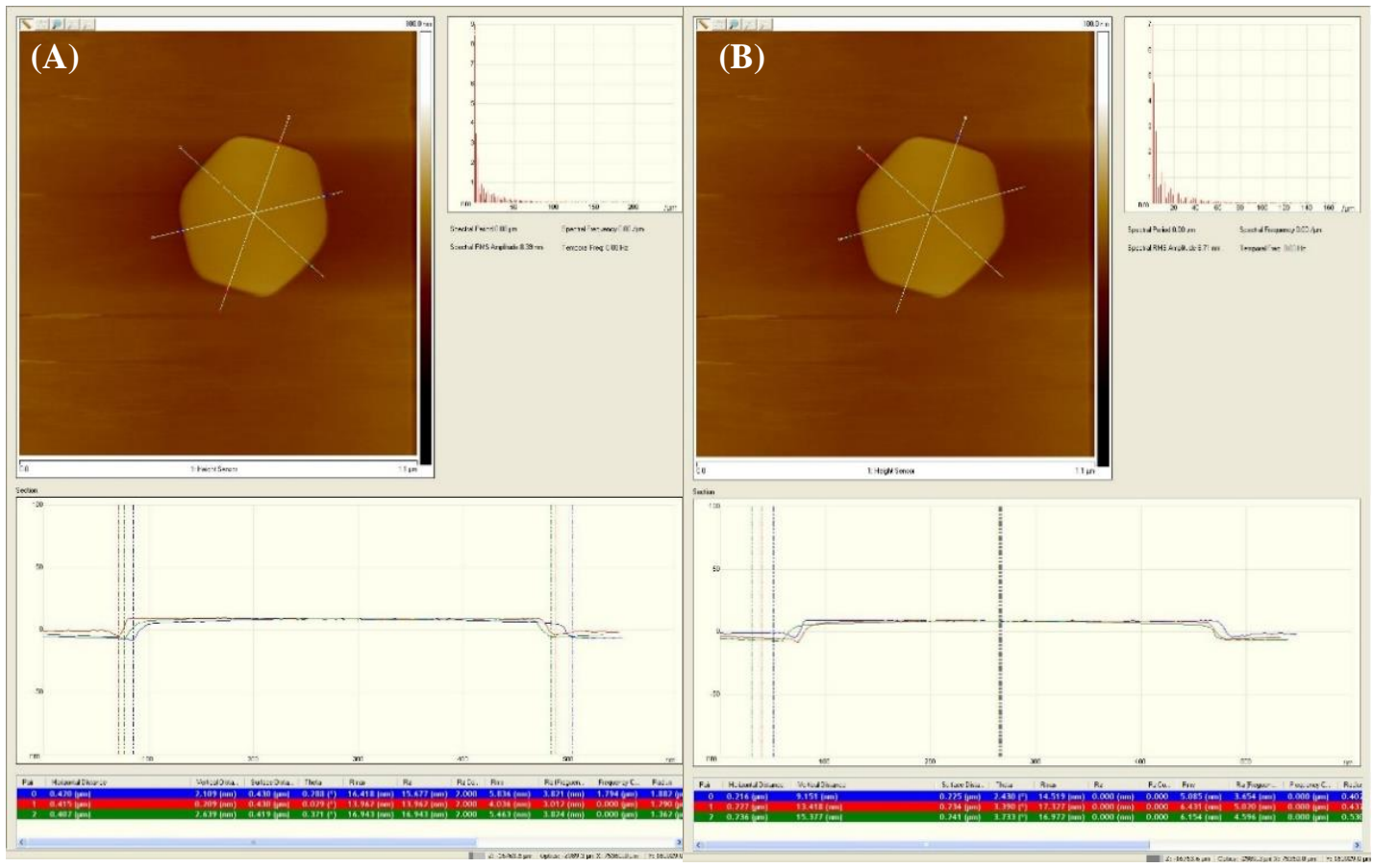

Figure S2. AFM analysis method on size (A) and thickness (B) of hematite nanoplates. 

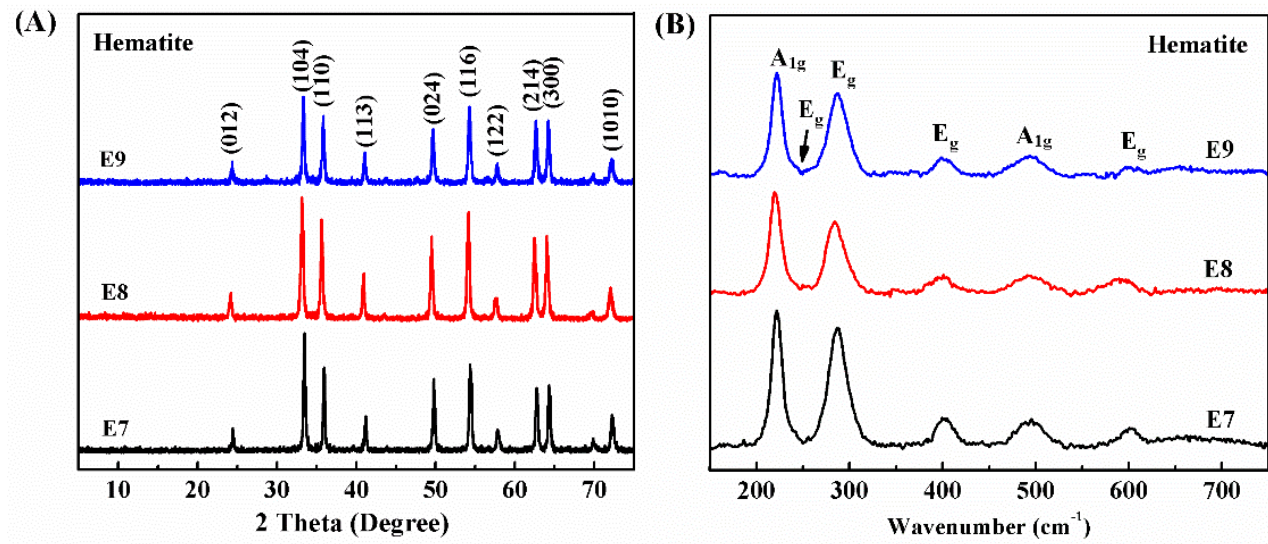

Figure S3. XRD patterns (A) and Raman spectra (B) of hematite synthesized at different volume ratio of ethanol to water. $\mathrm{E} 7 \mathrm{R}_{\mathrm{E} / \mathrm{w}}$ was 80:20; $\mathrm{E} 8 \mathrm{R}_{\mathrm{E} / \mathrm{w}}$ was 50:50; $\mathrm{E} 9 \mathrm{R}_{\mathrm{E} / \mathrm{w}}$ was 0:100. The concentration of $\mathrm{FeCl}_{3}$ and $\mathrm{NaAc}$ were $0.1 \mathrm{~mol} \cdot \mathrm{L}^{-1}$ and $1.0 \mathrm{~mol} \cdot \mathrm{L}^{-1}$, respectively. The reaction temperature was $180^{\circ} \mathrm{C}$ and the reaction time was 12 hours. 


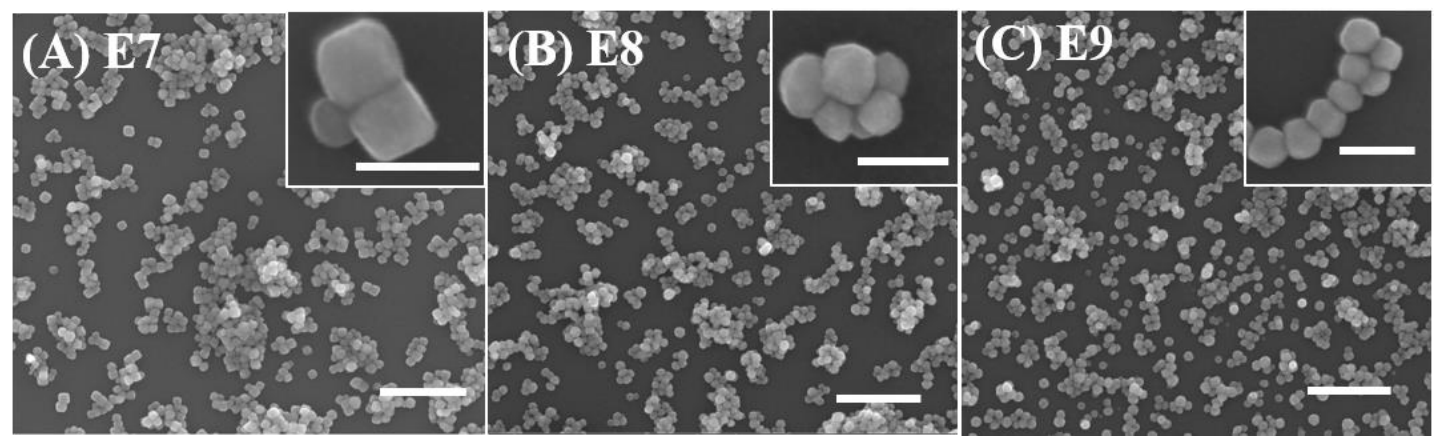

Figure S4. SEM images of hematite synthesized at different volume ratio of ethanol to water. (A) E7 $\mathrm{R}_{\mathrm{E} / \mathrm{w}}$ was 80:20; (B) E8 was $\mathrm{R}_{\mathrm{E} / \mathrm{w}}$ was 50:50; (C) $\mathrm{E} 9 \mathrm{R}_{\mathrm{E} / \mathrm{w}}$ was 0:100. The concentration of $\mathrm{FeCl}_{3}$ and $\mathrm{NaAc}$ were $0.1 \mathrm{~mol} \cdot \mathrm{L}^{-1}$ and $1.0 \mathrm{~mol} \cdot \mathrm{L}^{-1}$, respectively. The reaction temperature was $180^{\circ} \mathrm{C}$ and the reaction time was 12 hours. The inset scale bars are $500 \mathrm{~nm}$ in low magnification SEM images and $100 \mathrm{~nm}$ in the inserted high magnification SEM images. 

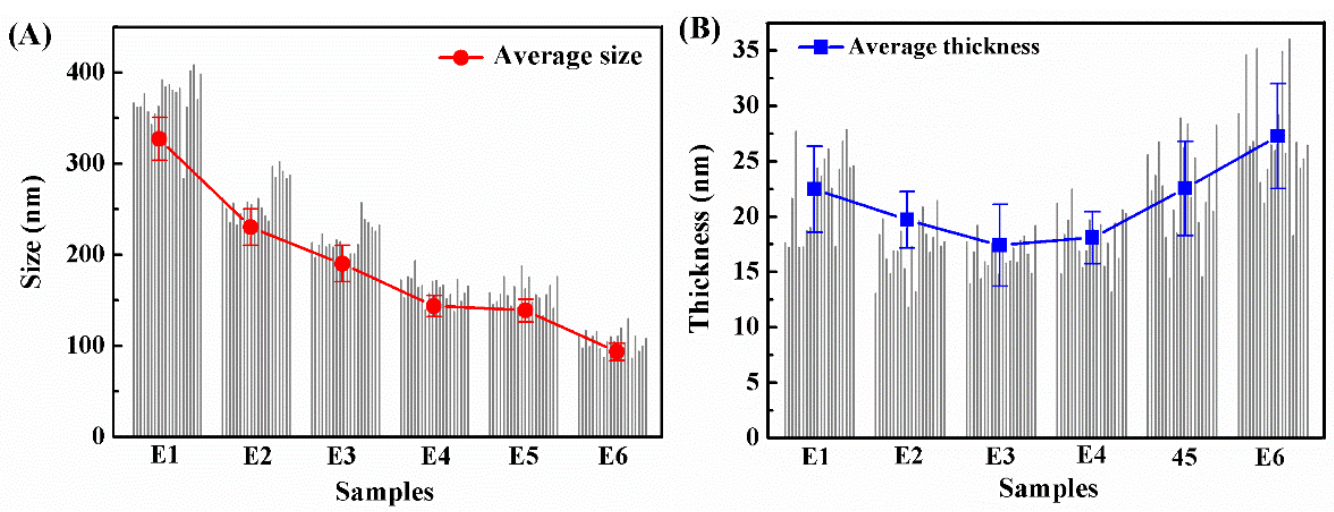

Figure S5. Size and thickness of hematite synthesized at different volume ratio of ethanol to water. (A) Size of as-synthetic hematite nanoplates; (B) thickness of as-synthetic hematite nanoplates; E1 $\mathrm{R}_{\mathrm{E} / \mathrm{W}}$ was 100:0; E2 $\mathrm{R}_{\mathrm{E} / \mathrm{w}}$ was 98:2; $\mathrm{E} 3 \mathrm{R}_{\mathrm{E} / \mathrm{w}}$ was 96:4; $\mathrm{E} 4 \mathrm{R}_{\mathrm{E} / \mathrm{w}}$ was 94:6; E5 $\mathrm{R}_{\mathrm{E} / \mathrm{w}}$ was 92:8; E6 $\mathrm{R}_{\mathrm{E} / \mathrm{w}}$ was 90:0. The concentration of $\mathrm{FeCl}_{3}$ and $\mathrm{NaAc}$ were $0.1 \mathrm{~mol} \cdot \mathrm{L}^{-1}$ and $1.0 \mathrm{~mol} \cdot \mathrm{L}^{-1}$, respectively. The reaction temperature was $180^{\circ} \mathrm{C}$ and the reaction time was 12 hours. 
(A)

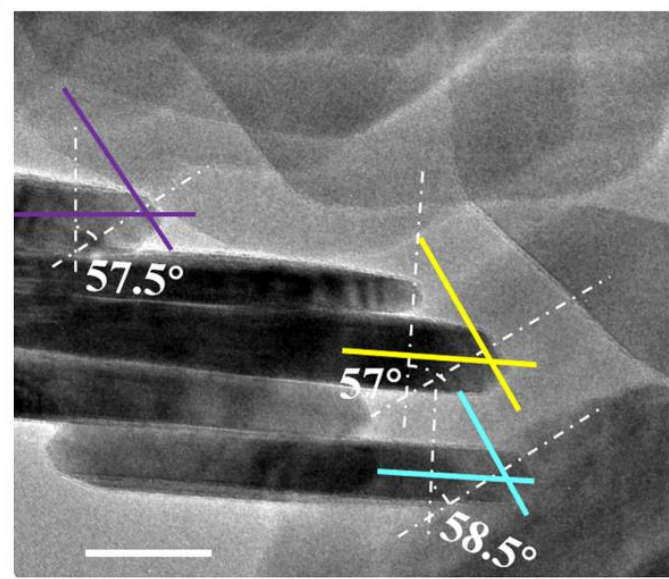

(B)

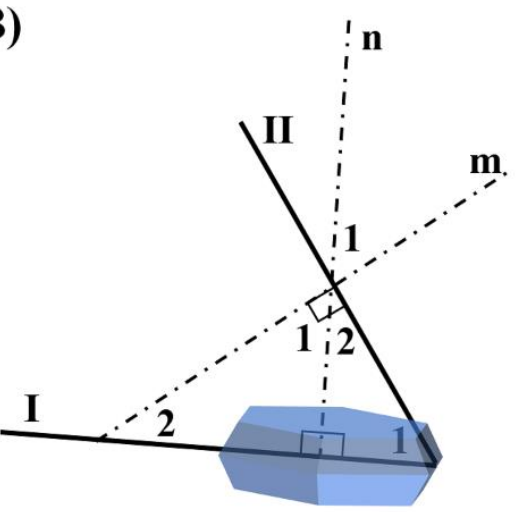

average angle $1=57.66^{\circ}$

Figure S6. (A) TEM images of sample E3 viewed perpendicular to the basal direction. (B) Angle information between the top facet and side facets, and the trigonometric calculation about the facets angles. Here, we define I and II as the basal and edge surfaces, respectively, with $\mathrm{m}$ and $\mathrm{n}$ as their respective normal directions. As shown in (B), the angle of surface I and II is equal to the angle between $\mathrm{m}$ and $\mathrm{n}$. The scale bar is $20 \mathrm{~nm}$.

\section{Note:}

The angle between two planes $\mathrm{p}_{1}$ and $\mathrm{p}_{2}$ is shown as

$$
\varphi=\cos ^{-1} \frac{p_{1} G^{-1} p_{2}^{T}}{\sqrt{p_{1} G^{-1} p_{1}^{T}} \sqrt{p_{2} G^{-1} p_{2}^{T}}}
$$

For the hexagonal crystal (hematite), the angle between (001) and (012) planes can be simplified as

$$
\cos \varphi=\frac{1}{\sqrt{\left(\frac{c^{2}}{3 b^{2}}+1\right)}}
$$

From a published .cif (Am. Miner. 1966, 51 123-129), a=5.038 and c=13.6467 angstrom, which gives theta of approx. 57.6. The average angle we measured from the TEM images is 57.66, which indicated the edge surface is $\{012\}$. 


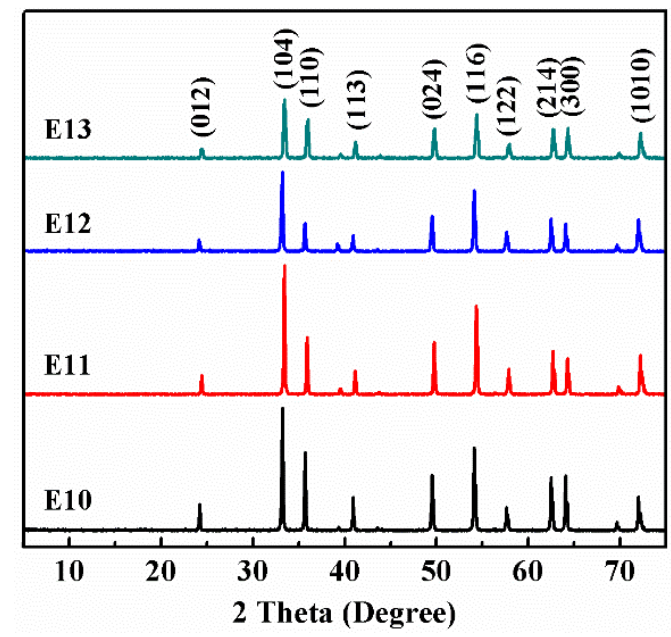

Figure S7. XRD patterns of hematite synthesized with different concentration of iron ions. $\mathrm{E} 10 \mathrm{C}_{\mathrm{Fe}} \mathrm{Was} 0.005$ $\mathrm{mol} \cdot \mathrm{L}^{-1}$; E11 $\mathrm{C}_{\mathrm{Fe}}$ was $0.01 \mathrm{~mol} \cdot \mathrm{L}^{-1}$; E12 $\mathrm{C}_{\mathrm{Fe}}$ was $0.025 \mathrm{~mol} \cdot \mathrm{L}^{-1}$; $\mathrm{E} 13 \mathrm{C}_{\mathrm{Fe}}$ was $0.05 \mathrm{~mol} \cdot \mathrm{L}^{-1}$. The concentration of $\mathrm{NaAc}$ was $1.0 \mathrm{~mol} \cdot \mathrm{L}^{-1}$, and the volume ratio of ethanol to water was $96: 4$. The reaction temperature was $180^{\circ} \mathrm{C}$ and the reaction time was 12 hours. 

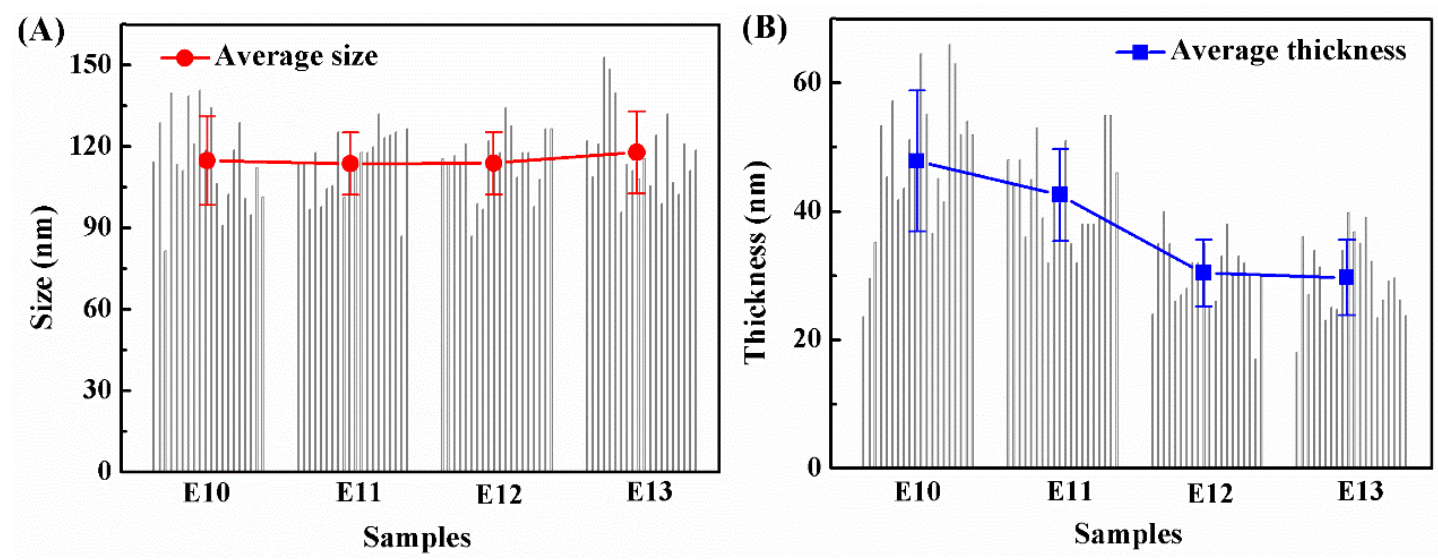

Figure S8. Size (A) and thickness (B) of hematite synthesized with the different concentration of iron ion. E10 $\mathrm{C}_{\mathrm{Fe}}$ was $0.005 \mathrm{~mol} \cdot \mathrm{L}^{-1}$; E11 $\mathrm{C}_{\mathrm{Fe}}$ was $0.01 \mathrm{~mol} \cdot \mathrm{L}^{-1}$; E12 $\mathrm{C}_{\mathrm{Fe}}$ was $0.025 \mathrm{~mol} \cdot \mathrm{L}^{-1}$; E13 $\mathrm{C}_{\mathrm{Fe}}$ was $0.05 \mathrm{~mol} \cdot \mathrm{L}^{-}$ 1. The concentration of $\mathrm{NaAc}$ was $1.0 \mathrm{~mol} \cdot \mathrm{L}^{-1}$, and the volume ratio of ethanol to water was $96: 4$. The reaction temperature was $180^{\circ} \mathrm{C}$ and the reaction time was 12 hours. 

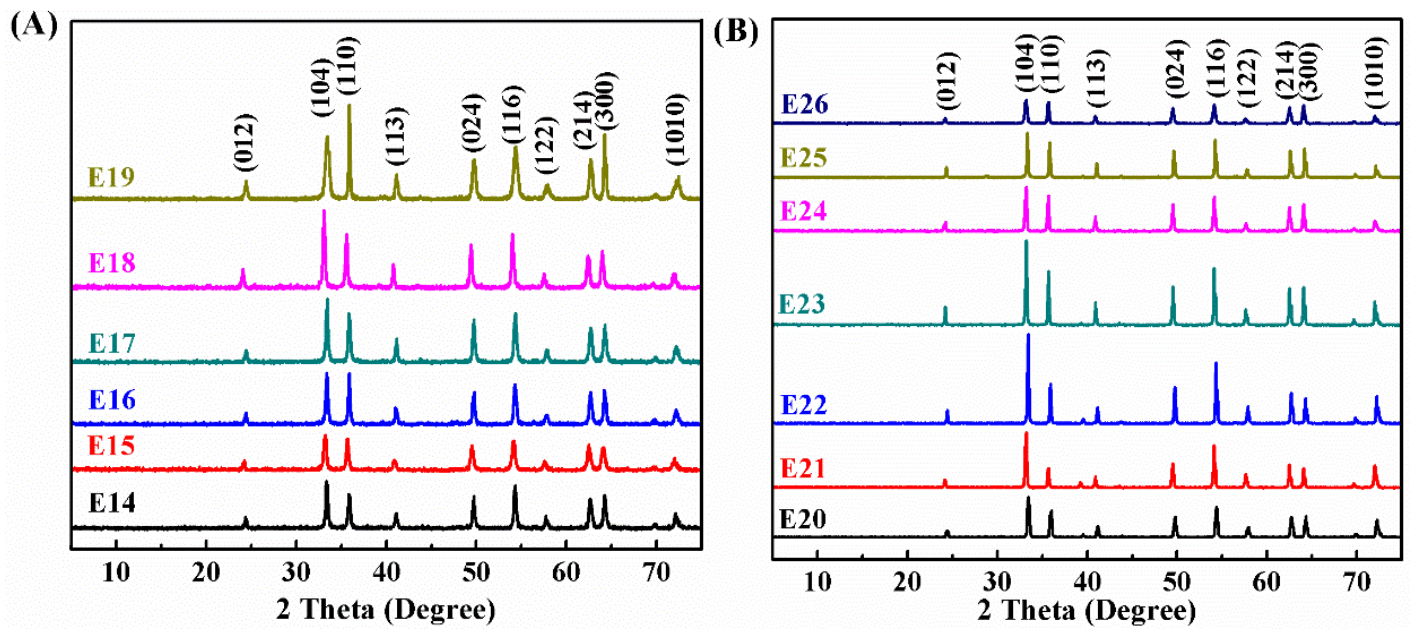

Figure S9. XRD patterns of hematite synthesized with different pH. E14, pH 2; E15, pH 3; E16, pH 4; E17, pH 5; E18, pH 6; E19, pH 7; E20, pH 8; E21, pH 9; E22, pH 10; E23, pH 10.5; E24, pH 11; E25, pH 12; E26, $\mathrm{pH}$ 13. The concentration of $\mathrm{FeCl}_{3}$ and $\mathrm{NaAc}$ were $0.1 \mathrm{~mol} \cdot \mathrm{L}^{-1}$ and $1.0 \mathrm{~mol} \cdot \mathrm{L}^{-1}$, respectively. The volume ratio of ethanol to water was $96: 4$. The reaction temperature was $180^{\circ} \mathrm{C}$ and the reaction time was 12 hours. 

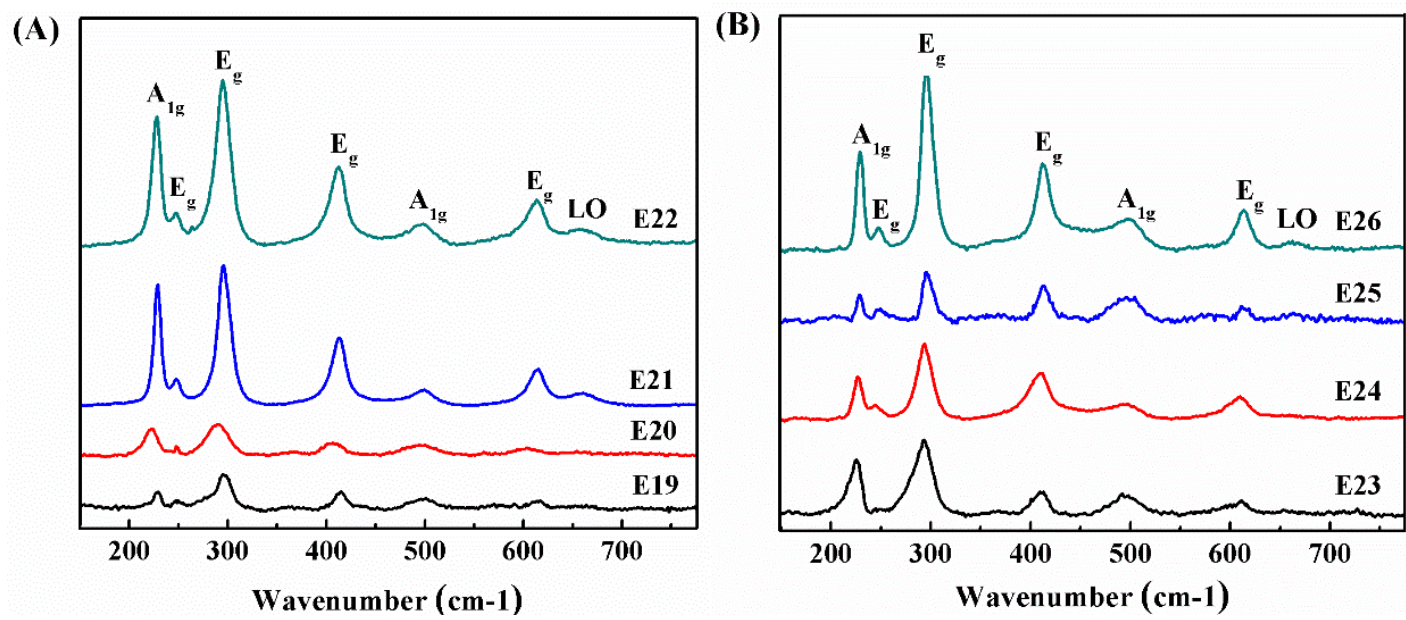

Figure S10. Raman of hematite synthesized with different pH. E19, pH 7; E20, pH 8; E21, pH 9; E22, pH 10; $\mathrm{E} 23, \mathrm{pH} 10.5 ; \mathrm{E} 24, \mathrm{pH} 11 ; \mathrm{E} 25, \mathrm{pH} 12 ; \mathrm{E} 26, \mathrm{pH} 13$. The concentration of $\mathrm{FeCl}_{3}$ and $\mathrm{NaAc}$ were $0.1 \mathrm{~mol} \cdot \mathrm{L}^{-1}$ and $1.0 \mathrm{~mol} \cdot \mathrm{L}^{-1}$, respectively. The volume ratio of ethanol to water was $96: 4$. The reaction temperature was $180^{\circ} \mathrm{C}$ and the reaction time was 12 hours. 


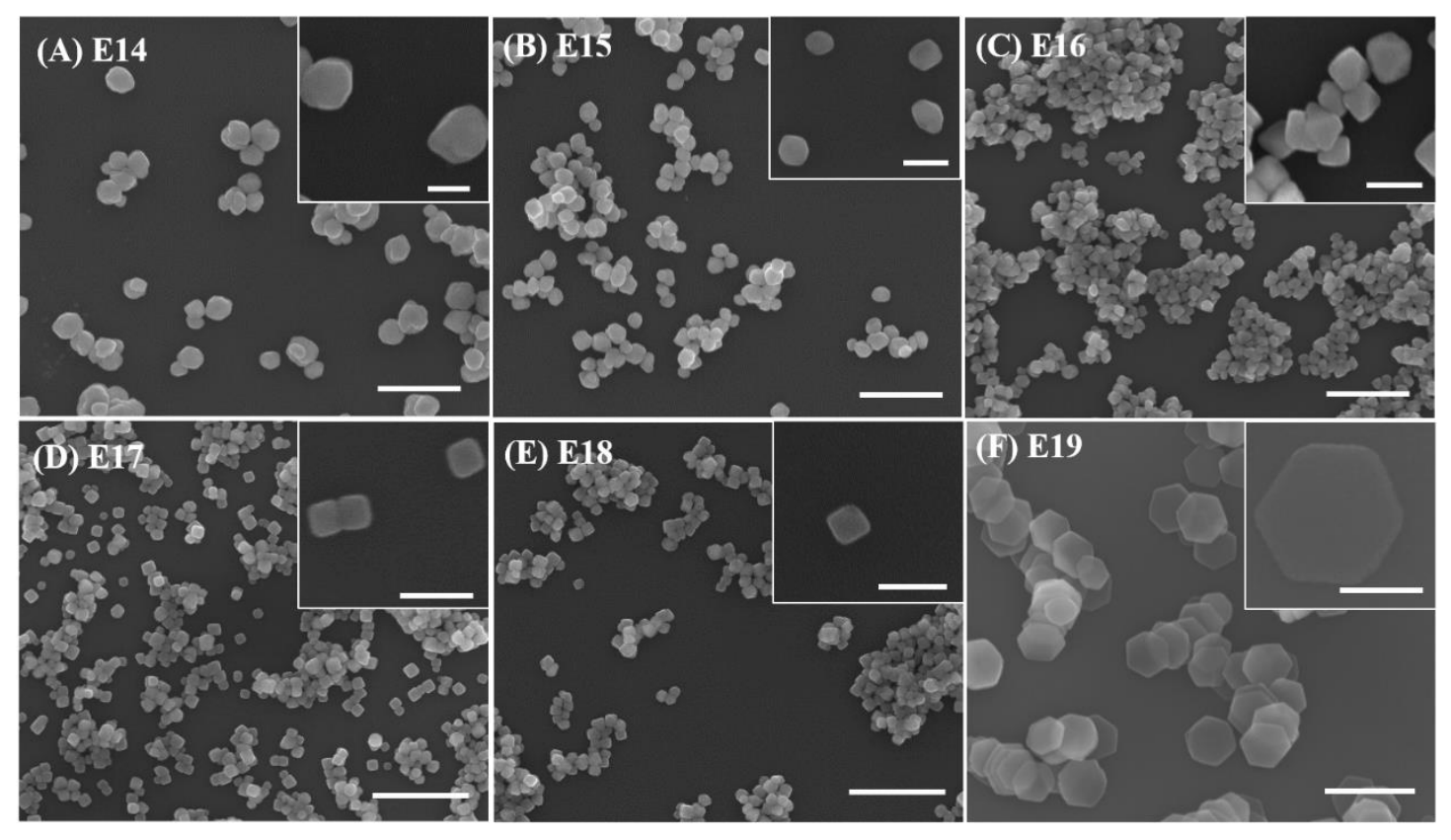

Figure S11. SEM images of hematite synthesized at different pH. E14, pH 2; E15, pH 3; E16, pH 4; E17, pH 5; E18, pH 6; E19, $\mathrm{pH}$ 7. The concentration of $\mathrm{FeCl}_{3}$ and $\mathrm{NaAc}$ were $0.1 \mathrm{~mol} \cdot \mathrm{L}^{-1}$ and $1.0 \mathrm{~mol} \cdot \mathrm{L}^{-1}$, respectively. The volume ratio of ethanol to water was $96: 4$. The reaction temperature was $180^{\circ} \mathrm{C}$ and the reaction time was 12 hours. The inset scale bars are $500 \mathrm{~nm}$ in low magnification SEM images and $100 \mathrm{~nm}$ in the inserted high magnification SEM images. 

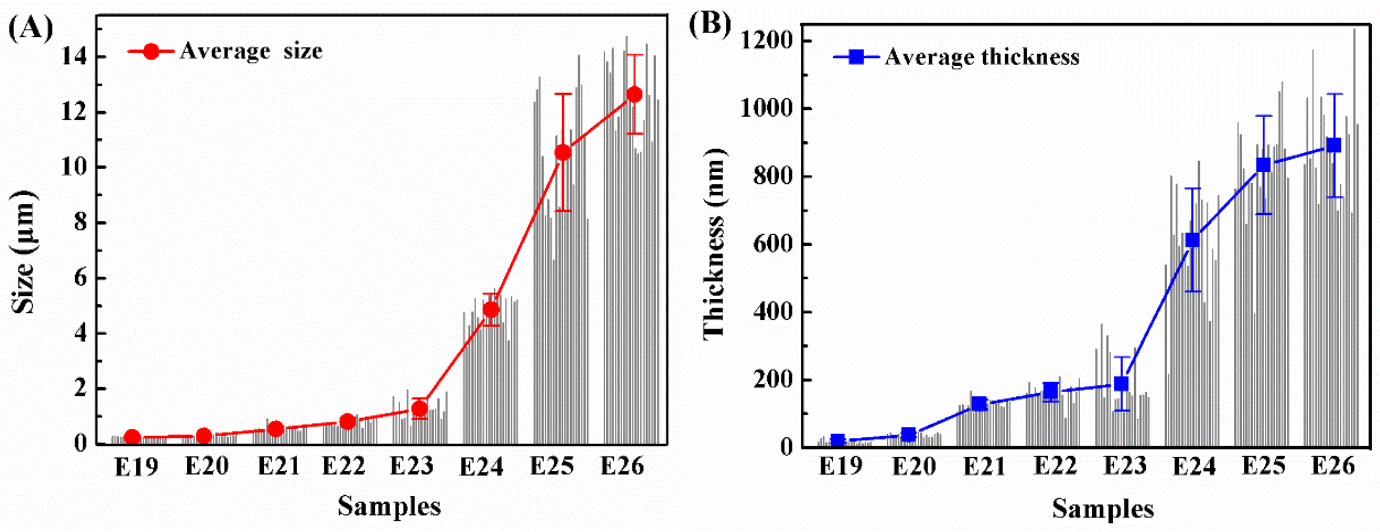

Figure S12. (A) Size and (B) thickness of hematite synthesized at different pH. E19, pH 7; E20, pH 8; E21, pH 9; E22, pH 10; E23, pH 10.5; E24, pH 11; E25, pH 12; E26, pH 13. The concentration of $\mathrm{FeCl}_{3}$ and $\mathrm{NaAc}$ were $0.1 \mathrm{~mol} \cdot \mathrm{L}^{-1}$ and $1.0 \mathrm{~mol} \cdot \mathrm{L}^{-1}$, respectively. The volume ratio of ethanol to water was $96: 4$. The reaction temperature was $180^{\circ} \mathrm{C}$ and the reaction time was 12 hours. 
(A)

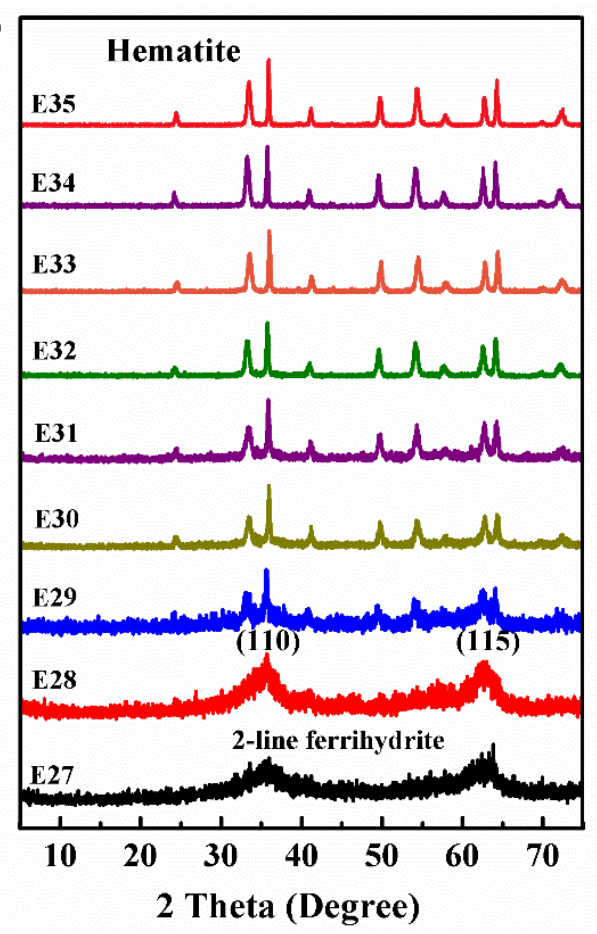

(B)

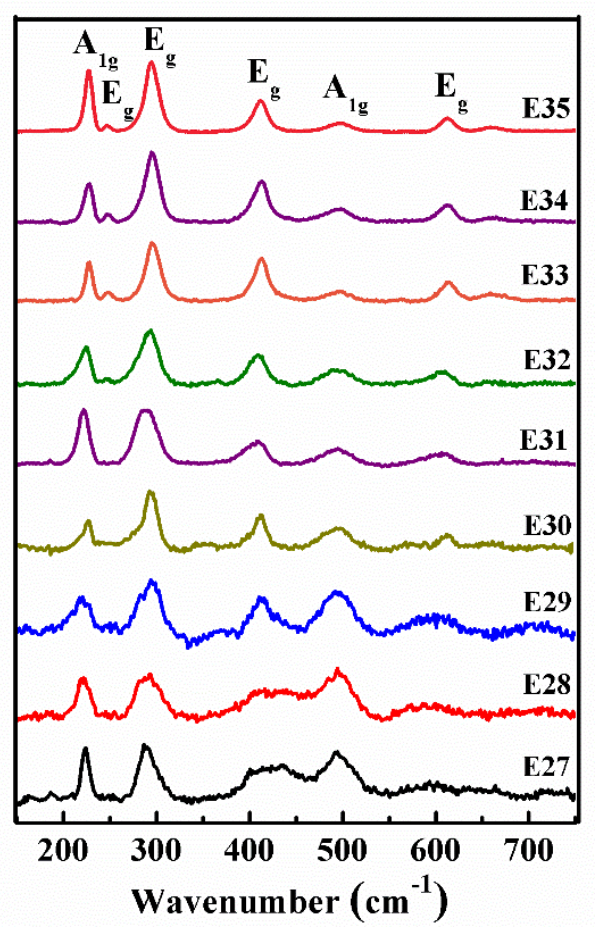

Figure S13. (A) XRD patterns and (B) Raman of hematite synthesized at the different time. (A) E27, $1.0 \mathrm{~h}$; (B) E28, 1.5 h; (C) E29, 2.0 h; (D) E30, 3.0 h; (E) E31, 4.0 h; (F) E32, 5.0 h; (G) E33, 6.0 h; (H) E34, 9.0 h; (I) E35, $12.0 \mathrm{~h}$. The concentration of $\mathrm{FeCl}_{3}$ and $\mathrm{NaAc}$ were $0.1 \mathrm{~mol} \cdot \mathrm{L}^{-1}$ and $1.0 \mathrm{~mol} \cdot \mathrm{L}^{-1}$, respectively. The volume ratio of ethanol to water was $96: 4$. The reaction temperature was $180^{\circ} \mathrm{C}$. 


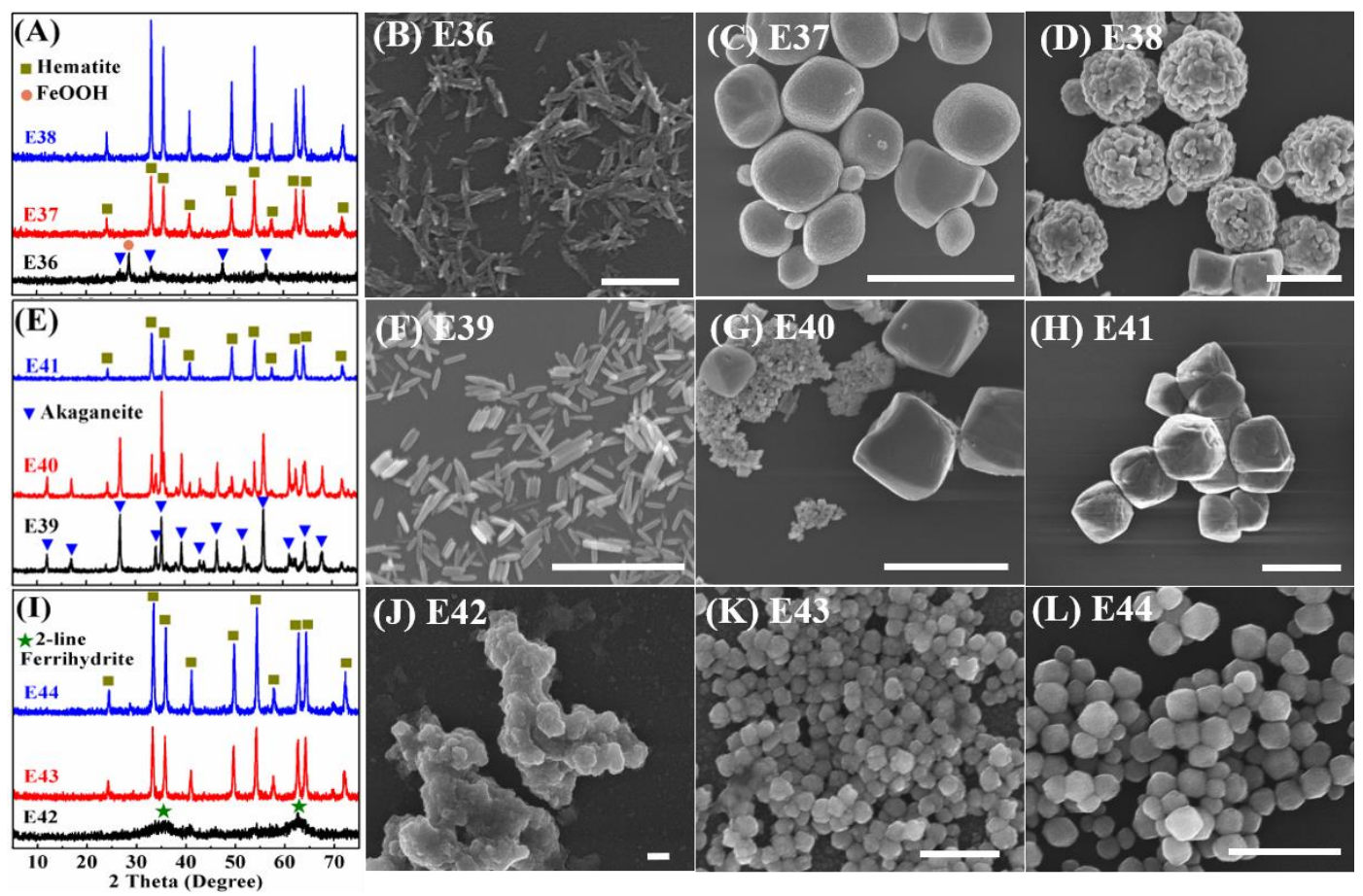

Figure S14. (A), (E) and (I) XRD patterns and (B)-(D), (F)-(H) and (J)-(L) SEM images of hematite synthesized at different conditions in the different time. (A)-(D) are synthesized by Fe(III) and 96\% Ethanol, E36, 1 h, E37, 2 h, E38, 6 h. (E)-(H) are synthesized by Fe(III) and water, E39, 1 h, E40, 2 h, E41, 6 h. (A)(D) are synthesized by Fe(III), NaAc and water, E42, 1 h, E43, 2 h, E44, 6 h. The concentration of $\mathrm{FeCl}_{3}$ and NaAc were $0.1 \mathrm{~mol} \cdot \mathrm{L}-1$ and $1.0 \mathrm{~mol} \cdot \mathrm{L}-1$, respectively. The reaction temperature was $180^{\circ} \mathrm{C}$. The scale bars in (B), (J), (k), and (L) are $200 \mathrm{~nm}$; in (C), (D), (F), (G), and (H) are $2 \mu \mathrm{m}$. 
Table S1. The size and thickness of hematite synthesized with different volume ratio of ethanol to water

\begin{tabular}{llllll}
\hline Entry & $\mathrm{R}_{\mathrm{E} / \mathrm{w}}$ & Size $(\mathrm{nm})$ & $\begin{array}{c}\text { Thickness } \\
(\mathrm{nm})\end{array}$ & \multicolumn{2}{c}{ Surface area percentage $(\%)$} \\
\cline { 5 - 6 } & & & & $\{001\}$ facets & $\{012\}$ facets \\
\hline 1 & $100: 0$ & $425 \pm 30$ & $22 \pm 4$ & 88.4 & 11.6 \\
2 & $98: 2$ & $299 \pm 25$ & $19 \pm 3$ & 86.1 & 13.9 \\
3 & $96: 4$ & $247 \pm 25$ & $17 \pm 4$ & 85.7 & 14.3 \\
4 & $94: 6$ & $187 \pm 15$ & $18 \pm 2$ & 80.4 & 19.6 \\
5 & $92: 8$ & $180 \pm 16$ & $22 \pm 4$ & 76.3 & 23.7 \\
6 & $90: 10$ & $120 \pm 12$ & $27 \pm 5$ & 63.5 & 36.5 \\
\hline
\end{tabular}


Table S2. The size and thickness of hematite products synthesized with different concentrations of Fe ions.

\begin{tabular}{llllll}
\hline Entry & $\mathrm{C}_{\mathrm{Fe}}(\mathrm{mM})$ & Size $(\mathrm{nm})$ & $\begin{array}{c}\text { Thickness } \\
(\mathrm{nm})\end{array}$ & \multicolumn{2}{c}{ Surface area percentage (\%) } \\
\cline { 5 - 6 } & & & & $\{001\}$ facets & $\{012\}$ facets \\
\hline 10 & 0.005 & $115 \pm 16$ & $48 \pm 11$ & 51.7 & 48.3 \\
11 & 0.01 & $114 \pm 11$ & $43 \pm 7$ & 53.7 & 46.3 \\
12 & 0.025 & $114 \pm 12$ & $30 \pm 5$ & 62.5 & 37.5 \\
13 & 0.05 & $118 \pm 15$ & $29 \pm 6$ & 64.5 & 35.5 \\
\hline
\end{tabular}


Table S3. The size and thickness of the hematite with different $\mathrm{pH}$

\begin{tabular}{llllll}
\hline Entry & $\mathrm{pH}$ & Size $(\mu \mathrm{m})$ & Thickness $(\mathrm{nm})$ & \multicolumn{2}{c}{$\begin{array}{c}\text { Surface area percentage } \\
(\%)\end{array}$} \\
& & & & \multicolumn{2}{c}{$\begin{array}{l}\{001\} \text { facets } \\
\{012\} \text { facets }\end{array}$} \\
& & & & 82.8 & 17.2 \\
\hline 19 & 7 & $0.238 \pm 0.030$ & $19 \pm 6$ & 75.6 & 24.4 \\
20 & 8 & $0.288 \pm 0.040$ & $38 \pm 7$ & 64.0 & 36.0 \\
21 & 9 & $0.542 \pm 0.100$ & $128 \pm 15$ & 68.2 & 31.8 \\
22 & 10 & $0.808 \pm 0.130$ & $164 \pm 27$ & 74.2 & 25.8 \\
23 & 10.5 & $1.270 \pm 0.360$ & $187 \pm 79$ & 77.2 & 22.8 \\
24 & 11 & $4.859 \pm 0.590$ & $612 \pm 153$ & 84.3 & 15.7 \\
25 & 12 & $10.543 \pm 2.130$ & $834 \pm 145$ & 85.8 & 14.2 \\
26 & 13 & $12.645 \pm 1.430$ & $891 \pm 152$ & & \\
\hline
\end{tabular}

